\title{
A New Mass-Market Outdoor Tourism Model Threats the Sustainability of Rural Environment in Spain: The Necessity for Regulation
}

\author{
Julia Escorihuela* \\ Manager of the Geologic Park of Aliaga, Spain \\ *Corresponding author: Julia Escorihuela, Manager of the Geologic Park of Aliaga, C\San Antonio s/n 44150, Aliaga, Teruel, Spain

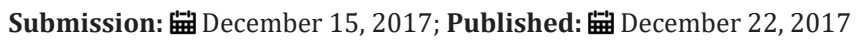

\begin{abstract}
People from cities are diversifying their touristic destinations, not only in summertime but also at weekends. As a consequence a mass-market tourism is emerging directed towards nearby natural environments. In this context, in the last decade in Spain a new outdoor tourism model is based on enjoying nature by means of hiking trails on sites with a high geological value. Therefore, knowing the hosting environment and its host capacity is crucial to balance this situation, and to avoid irreversible damages in sensible areas. Geotourism involves the education of the tourist, who not only learns the geology of the environment and its relevance, but also is informed and aware of the conservation of the environment. On the other hand, a coordinated action with stakeholders is crucial to generate a framework able to manage a touristic demand, and to provide the necessary facilities. This is the correct way to generate endogenous economic incomes and a sustainable use of territory.
\end{abstract}

Keywords: Geotursim; Geoethics; Hiking trails; Host capacity; Tourism unsustainability

The "Pull Effect" of The New Outdoor Tourism In Spain: The Hiking Trail Effect

Nowadays different kinds of tourism are emerging to react to the touristic demands, promoting active and participative outdoor and adventure activities [1], for instance canyoning, four-wheeler tracks, and hiking trails that are aimed at families and general public, and without other hosting facilities.

In this context, a new outdoor tourism model has appeared in the last decade in Spain, it is based on enjoying nature by means of hiking trails on sites with a high geological value. These geological and paleontological features make possible a singular landscape which appeal to this touristic activity.

This last type of tourism is being promoted by the municipalities of rural areas,-which are those that have the privileged geological heritage-, which are adapting tracks, elaborating informative panels, and, in addition, they are creating access roads to practically inaccessible places, and in most cases without providing a greater knowledge and understanding of the host environment.

This way, in recent years people from cities are diversifying their touristic destinations, not only in summertime but also at weekends. As a consequence a mass-market tourism is emerging directed towards nearby natural environments, and in many cases, with little use of local facilities (such as food stores, tourist lodgings, or restaurants), and therefore leaving little income in hosting areas.
This "pull effect" is transforming unknown places into poles of attraction during the weekends, generating sustainability problems in sensitive areas. So, if local managers do not react properly, this activity will be a threat to areas with high geological and ecological value.

By the same token, it is important to highlight the lack of regulatory measures towards visitors. Many geological and paleontological sites have been lost due to the absence of conservation plans [2]. And, as Hose suggested in 2011 [3], evaluation tools and lessons from their application in the $90 \mathrm{~s}$ in England in the development of geotourism have to be learned, so as not to repeat the result of the destruction of different geosites occurred.

Therefore, the objectives of this article are

1) To expose the aggressiveness of the dynamics of this new mass-market outdoor tourism model, and

2) To highlight the role of geotourism and geoethics for responsible managers, in order to safeguard the natural heritage in Spain.

The Necessity of Knowing the Hosting Environment: The Role of Geotourism and Geoconservation

Visits to protected areas increase the challenges of the 
managers in charge of balancing the protection of the environment and the recreation of the tourist, since visits will inevitably leave an imprint [4]. But this problem is even worse in areas of ecological relevance and not protected by any management figure, because of the fact that they are being damaged. This is the problem faced by more and more municipalities in the Spanish territory. In addition, this damage caused by visitors' influx will still be accentuated if the extreme drought in Spain continues, which causes scarce vegetation coverage in many mountains. This fact makes possible a fast degradation of any mass-market hiking activity in every rural track. Thus, knowing the hosting environment is crucial to balance this situation.

From rural development initiatives taking advantage of tourism, in the 90's a new discipline called geotourism appeared in Europe. This discipline involves the education of the tourist, who not only learns the geology of the environment and its relevance, but also is informed and aware of the conservation of the environment. At the beginning of any activity in the environment, geotourismcombined with ecotourism- provides an understanding of the nature resources that will be impacted by tourists (Figure 1) This is because one of the main purposes of the geotourism is the conservation of the natural environment [5], becoming a key factor of conservation. Otherwise, if we do not take these teaching and awareness forethoughts, the risk of damage will happen due to the "pull effect" towards visitors who do not adequately respect the geological and paleontological heritage [6] (Figure 1).

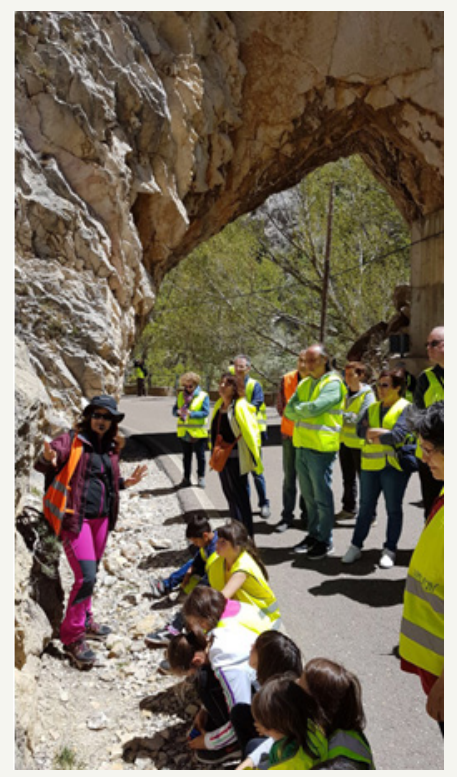

Figure 1: Explanation giving by the geotouristic guide to the tourists.

Geotourism, also, seeks a coordinated action among the stakeholders [7], trying to generate a framework able to manage a touristic demand, and to provide the necessary facilities. This is the correct way to generate endogenous economic incomes and a sustainable use of territory.
As Hose cited in 2013 [3] Geological (and paleontological) heritage should be considered as a natural cultural asset in the socio-economic development in these privileged areas, in the same way as cultural, archaeological and ethnographic heritage. Nevertheless, there are activities in natural environments with little or no cultural value, whose main interest is the entertainment without learning about the environment, and without seeking valuation or without getting to know the inhabitants of the visited place. These are mistakes whose short- term benefits -in the case they exist- are not comparable to the medium-term damages that they will generate in the hosting areas.

Application of Geoethics To Achieve Sustainable Development: The Introduction Of Geotouristic Guides, So As The Application of The "Host Capacity" Concept Are Essential

Given the unsustainability of the situations described above, several actions are necessary to take place urgently.

On the one hand, the application of the "host capacity" concept in every touristic project is required to find out the number of tourists allowed in every place without any damage. Thus, in fragile environments there is a clear necessity to distinguish between a particular tourism product and the sustainability of the environment, especially when the natural environment is the main element of attraction [8]. Since its impacts-noise, organic and inorganic waste, or trampling- can be the reasons for degradation and loss of value (fauna, flora and environment) intended to be offered to the tourist.

On the other hand, it is crucial to assess the environment through touristic guides of nature. And, in the case of areas of high geological values, the figure of the local geotouristic guide is reported as essential [7]. This guide must apply not only geological concepts, but also geoethics [9], and so they should transmit the responsibility of any action in the environment. In this way, guided- controlled visits will make possible an enjoyment based on recreation and respect, and this way, the activity can be sustainable in the long term. Respect not only includes the environment, but also the community. This type of tourism, of higher quality, would make a sustainable use of the environment, and a use of local facilities that would allow people of the territory to benefit from the reception of these visitors. This is the only sustainable local development way promoted by UNESCO within the framework of Geoparks [10].

\section{Conclusion}

After the episodes of degradation of natural environments that are occurring in rural areas by the "pull effect" of outdoor activities, the necessity to increase the cultural value of tourism in nature, putting the geological and paleontological heritage at the same level with the cultural and ethnological heritage is urgent.

It is essential the work of awareness that professionals linked to geology- through the application of the principles of geoethics. 
They should teach guides and people in the host municipalities, preparing them to manage visitors. In this context, the interpretative provision is essential, adapting to all types of public, so tourist can be given information with high quality, information about the environment, which generates knowledge at the same time they enjoy in nature.

Only with a greater knowledge of the environment and active conservation initiatives, sustainability of tourism in nature in Spain will be achieved.

\section{References}

1. Hose TA (2013) Geotourism in Almeria province, southeast Spain Tourism 55(3): 259-276.

2. Henriques MH, Pena dos Reis R, Brilha J, Mota T (2011) Geoconservation as an emerging geoscience. Geoheritage 3(2): 117-128.

3. Hose TA (2011) The English origins of geotourism (as a vehicle for geoconservation) and their relevance to current studies. Acta Geographica Slovenica 51(2): 343-360.

4. Marion JL, Reid SE (2007) Minimising visitor impacts to protected areas:
The efficacy of low impact education programmes. Journal of Sustainable Tourism 15(1): 5-27.

5. Newsome D, Dowling RK (2010) Geotourism: The tourism of geology and landscape. Good fellow publishers, Oxford, England, p. 246.

6. Escorihuela J, Dowling R (2015) Analysis of the geotouristic activity in the geologic park of Aliaga, Spain: Progress, threats and challenges for the future. Geoheritage 7(3): 299-306.

7. Escorihuela J (2017a) The role of the geotouristic guide in earth science education: Towards a more critical society of land management. Geoheritage, pp. 1-10.

8. Edwards JA, Priestley GK (1996) European perspectives on sustainable tourism. In: sustainable tourism? European Experiences, Wallingford, CAB International, pp. 189-198.

9. Escorihuela J (2017b) The contribution of the geotourism to the sustainable development: The role of geoethics. Arch \& Anthropol Open Acc 1(3): AAOA.000511.

10. UNESCO (1999) Programa de parques geológicos de la UNESCO una nueva iniciativa para promover una red mundial de parques geológicos, con miras a la salvaguardia y la ordenación de zonas que presentan características geológicas especiales. Reunión de París. 